\title{
The Usage of Civil Engineering Analysis in Order to Improve Cost and Material Management of Public Boarding School
}

\author{
Sheila Hani ${ }^{* 1)}$
}

${ }^{1}$ Department of Civil Engineering, Universitas Pembinaan Masyarakat Indonesia, Medan, 20214

\begin{abstract}
In the construction of structures, cost is one of the factors that support success. Cost is very important to meet all the needs of work ranging from material procurement to labor. For this reason, civil engineering analysis needs to be done to produce work cost planning as an initial guide in calculating building budget costs that include material, labor and unit price. In the civil engineering analysis of the the two-story building of Rumah Tahfiz, there were various kinds of structural works ranging from foundations to roofs, and also finishing in the form of floors to windows. Those work items make reading work design activities more complex. For this reason, the Tahfiz House Foundation requires the assistance of engineers in analyzing the drawing design, producing more reasonable material calculations and building costs using their own estimated price calculations. From the design analysis activities, Rumah Tahfiz Foundation can find out the details of building activities, materials used, and the cost requirements per section of structural work, aimed at measuring the cost needs until the structure was completed. The help of Civil engineering analysis on the building simplify Rumah Tahfiz foundation in understanding and implementing building process which have a sustainable impact on financial management for future operational learning activites.
\end{abstract}

Keywords: Reading drawing, Building cost estimation, Unit price of work

Abstrak. Dalam struktur bangunan, biaya adalah salah satu faktor pendukung keberhasilan. Biaya sangat penting dalam memenuhi seluruh kebutuhan mulai dari ketersediaan material sampai dengan tenaga kerja. Atas alasan ini, analisa teknik sipil diperlukan untuk menghasilkan rancangan biaya pekerjaan sebagai panduan awal dalam menghitung rancangan anggaran biaya yang mencakup material, tenaga kerja dan harga satuan. Dalam analisa keteknik-sipilan dari bangunan rumah tahfiz. berlantai dua, ada banyak pekerjaan struktur yang bervariasi, mulai dari pondasi sampai dengan atap serta finishing dari lantai hingga jendela. Untuk itulah, Yayasan

Rumah Tahfiz membutuhkan bantuan engineer sipil dalam menganalisa gambar *Corresponding author at: Civil Engineering, Universitas Pembinaan Masyarakat Indonesia, Medan, 20214

E-mail address: Sheilahani87@gmail.com 
rencana, menghasilkan perhitungan material yang masuk akal dan menghitung biaya bangunan menggunakan perhitungan harga satuan sendiri. Dari hasil analisa kegiatan, Yayasan Rumah Tahfiz dapat mengetahui detail kegiatan pembangunan, material yang digunakan, dan biaya yang dibutuhkan untuk tiap bagian pekerjaan struktur, yang bertujuan untuk menghitung biaya yang dibutuhkan sampai struktur selesai dibangun. Bantuan analisa engineer sipil mempermudah Yayasan Rumah Tahfiz dalam memahami dan mengimplementasikan proses pembangunan yang memiliki dampak berkelanjutan terhadap pengelolaan keuangan dan kegiatan operasional dalam aktifitas belajar mengajar kedepannya.

Kata Kunci: Membaca gambar, Estimasi biaya bangunan, Harga satuan pekerjaan Received 20 September 2019 | Revised 9 October 2019| Accepted 25October 2019

\section{Introduction}

Building construction is a combination of activities carried out within a certain period of time that has a limit. In implementing a project, issues related to labor, wages, and materials are important things that need to be taken into account. To achieve these development objectives, resources are needed which consist of man, materials, machines, money and methods.

Those source are worthed for any type of construction even for small project construction. Skilled man source that didn't support with good method would not give best result for the construction. So did for other source, large amount of money without supported with good material will resulted bad construction. The combination of all those good sources will give maximum result and satisfaction, while big loss came from inaccurate combination of those sources.

The success of a construction project can be determined through the application of construction management in accordance with the stages, namely planning, implementation and supervision. In carrying out these stages it is necessary to have a Cost Budget Plan (RAB) which has a significant role. The construction stage that is carried out must have problems related to the management of the construction budget. Of the issues arising mentioned, we need a design cost that is commonly known as cost estimation [1].

In planning a project budget, it is necessary to analyze the unit price of the work as a guideline in calculating the cost budget design. Estimated amount of material and labor requirements in the building work process plays an important role in quality control and quantity of work [2]. 
In the conceptual stage, it is necessary to estimate the costs all over the part by providing an overview of the costs that will be needed in working on the construction before the arrival of detailed information about the type of development work to be carried out. The role of cost estimation in the conceptual stage is very important in determining the scope of work so that in the estimation of the conceptual stage a high degree of accuracy is needed [3].

Cost estimate design is an important activity in starting structure development, so the charity foundation of Rumah Tahfiz hardly needs to learn and understand about the design reading, interpreting drawing design and building cost estimation. Interpreting an engineering drawing was quite difficult without assistance of a professional. Some steps could be taken to understand an engineering drawing, such as: read symbols; get along with measurement including height, width, depth; and also to understand the position from any direction viewed [4].

\section{Methods}

The method used in reading drawing design, completing analysis of the budget design and analysis of unit price work explained in the next paragraph.

\section{Procedure}

This is the step by step in analysis building design to produce construction cost estimate:

1. First step needed is to analyse drawing design given, such as: scale, plan, building size, detail, and other aspect related to drawing.

2. Interpreting the drawing into structured design activites from foundation to roof construction

3. Calculate the exact quantity of every piece of material and determining every hour of labor from each structural activities.

4. Count the unit price of those material and labor.

5. The last action taken was to accumulate the total cost of the unit price counting.

\section{Results and Discussion}

From the results of the analysis of building calculation that have been carried out in the community service in one of Islamic public boarding school, it is known that the committee of Rumah Tahfiz foundation have been more educated in accordance with 
the explanation of the results. The explanation from the result of the analysis of building calculation divided into some aspect was:

The ability of reading building design and interprete it into worksheet. An early design came to the committee of Rumah Tahfiz foundation about two years ago and the design need to be built soon. Due to the lack of knowledge about structure and cost, the committee needs a hand of an expert in structure. An example of design drawing shown in Figure 1.

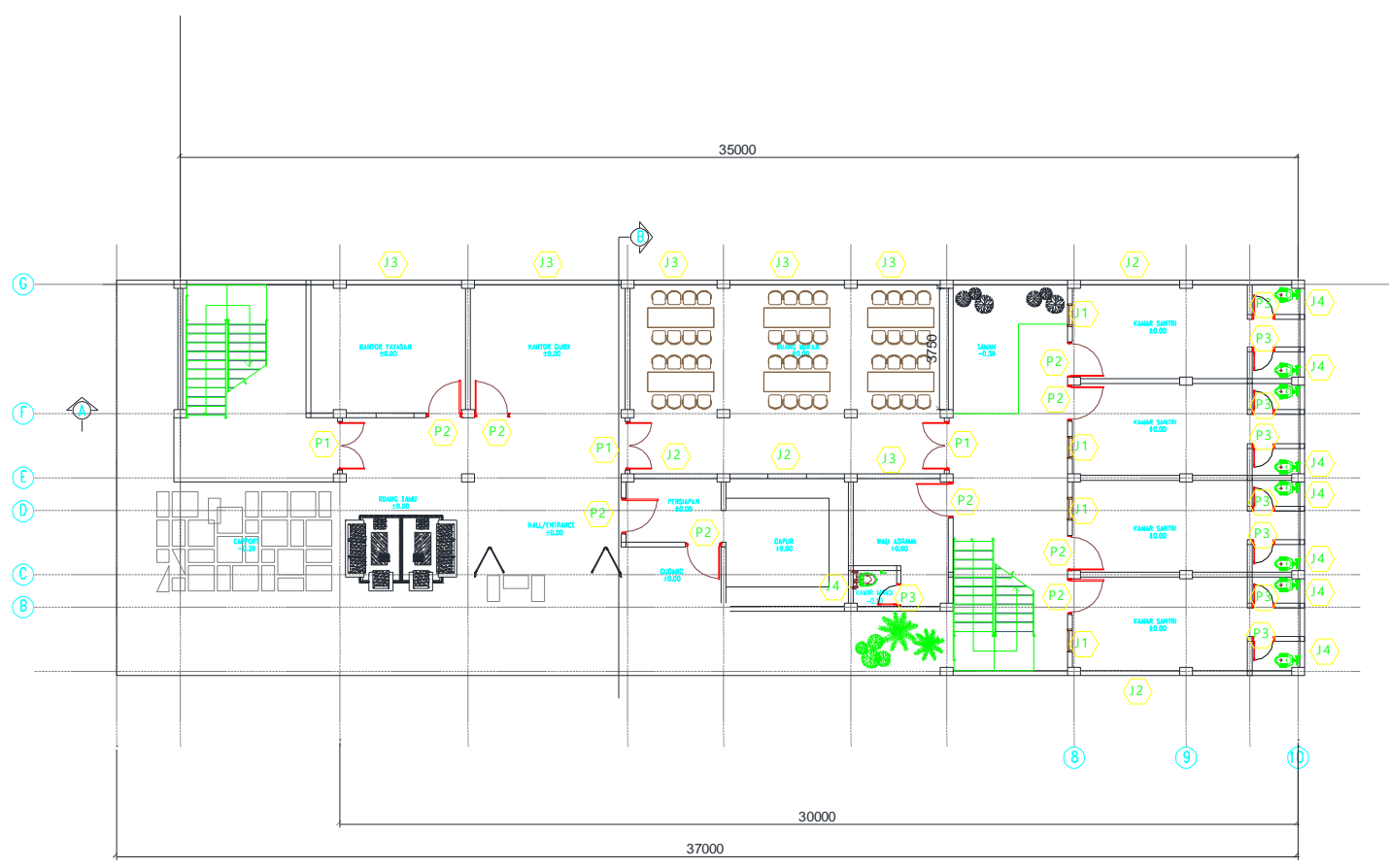

Figure 1. Plan of the first floor

From the figure 1, the unengineered person could only describe that it was a common plan that show the area of first floor, the location of walls, doors, windows and stairs. But an engineer could explain the result as: area of each partition; the position of the walls, doors, windows and stairs; explanation of each room, including the function and the length; the leveling of the floor; wall thickness, length of the doors and windows.

a. Projecting drawing into structural activities. A drawing plan explain many structural activities. For example, the wall thickness part. The explanation of this part was: build the wall using the brick; wall plastering; glass block installing.

b. Comprehending the step by step of structural construction from the lower structure to the upper structure. Our understanding will help us in supervising the building construction.

c. Define the amount of material. As long as our understanding of technical activites increased, we could continue with define the amount of the material and labor. As 
an example, in the wall thickness activity, we need material such as bricks, cement and sand for plastering, and then the blocks.

Building cost estimation. Linked data from activities and material provide complete cost estimation requirement. Table 1 showed an example taken from a section on how an activity could be count and produced cost estimation..

Table 1. Cost estimation from structural activities (random activities)

\begin{tabular}{|c|c|c|c|c|}
\hline $\begin{array}{l}\text { Activities } \\
\text { (a) }\end{array}$ & $\begin{array}{c}\text { Material } \\
\text { (b) }\end{array}$ & $\begin{array}{l}\text { Quantity Unit } \\
\text { (c) }\end{array}$ & $\begin{array}{l}\text { Unit Price } \\
\text { (d) }\end{array}$ & $\begin{array}{l}\text { Cost Estimation } \\
\text { (c) } \mathrm{x}(\mathrm{d})\end{array}$ \\
\hline $\begin{array}{l}\text { Build the wall in } \\
\text { section A }\end{array}$ & $\begin{array}{l}\text { Brick } \\
\text { Cement } \\
\text { Sand } \\
\text { Labor }\end{array}$ & $46,2 \mathrm{~m}^{2}$ & Rp. $172.500 / \mathrm{m}^{2}$ & Rp. 7.969.500,- \\
\hline $\begin{array}{l}\text { Concrete Slab } \\
\text { on the first floor }\end{array}$ & $\begin{array}{l}\text { Cement } \\
\text { Sand } \\
\text { Aggregate }\end{array}$ & $41,43 \mathrm{~m}^{3}$ & Rp. $705.000 / \mathrm{m}^{3}$ & Rp. 29.211.161,- \\
\hline
\end{tabular}

\section{Conclusions}

Based on the activity of the civil engineering analysis on two story building Rumah Tahfiz, we can conclude that design drawing which is interpreted into construction activities lead the committee to take step by step in constructing and supervising the building project. Material estimation taken from design drawing gives the committee brief expalanation on material needed for each construction work. Building cost estimation become a guideline for the committee in estimating the amount of cost to be issued and needed. The unit price of work on the cost estimation help the committee in spending money to supply the material. The assistance of a structural engineer is needed in order to projecting design become an understandable work sheet for the unengineered one.

\section{References}

[1] Q.S., Aulia, E.U. Saifoe, H., M.Hamzah. 2014. Analisa perbandingan harga satuan pekerjaan beton bertulang berdasarkan SNI dan Software Ms. Project (The analysis of Reinforced Concrete Unit Price based on SNI compare to The Ms. Project Software). Jurnal Mahasiswa Teknik Sipil Universitas Brawijaya, 1(2): 1-8.

[2] Sompie, B.F., Sibi, M., dan Pratasis, P. 2014. Analisis koefisien harga satuan tenaga kerja di lapangan dengan membandingkan analisis SNI dan analisis BOW pada pembesian dan bekisting kolom (The analysis of Labor Unit Price based on SNI compared to BOW analysis on column rebar and formwork). Jurnal Sipil Statik, 2(2): 81-93. 
[3] Roring, H.S.D., Sompie, B.F., Mandagi, R.J.M. 2014. Model estimasi biaya tahap konseptual konstruksi bangunan gedung dengan metode parametric Studi kasus pada bangunan gedung publik di wilayah Kota Manado dan kabupaten/kota sekitarnya (Model of Cost Estimation on Conseptual Stage of Building Construction Using Parametric Method Case Study on Building in The Manado City Area and Its Surrounding). Jurnal Ilmiah Media Engineering Universitas Sam Ratulangi, 2(2): 103-108.

[4] Jensen, Cecil H. Helsel, Jay D. 2012. Interpreting engineering drawing. Delmar Learning Press, United States. 